\title{
SERIOUS OCCUPATIONAL HEALTH AND SAFETY INCIDENTS IN THE OIL AND GAS INDUSTRY: LEGAL ISSUES AND RECOMMENDATIONS
}

\author{
KELLI GRIER $^{*}$ AND E. JANE SIDNELL ${ }^{* *}$
}

\begin{abstract}
Written primarily for in-house counsel, this article addresses some of the complex legal issues that arise in response to a serious incident in the oil and gas industry. The authors review the relevant reporting obligations under the Occupational Health and Safety Act and provide an overview of the legal issues relating to the privacy of medical records, drug and alcohol testing, privilege, and legal holds. The authors conclude by offering their recommendations regarding policies that should be in place before an incident occurs, as well as actions that should be taken in the immediate aftermath of any serious incident.
\end{abstract}

\begin{abstract}
Écrit essentiellement à l'intention d'avocats internes, cet article aborde des questions juridiques complexes découlant d'un incident grave dans le secteur pétrolier et gazier. Les auteurs examinent les obligations pertinentes en matière de présentation de rapports en vertu de la Loi sur la santé et sécurité au travail et donnent un aperçu des questions juridiques relatives au caractère privédes dossiers médicaux, du dépistage de drogues et de l'alcool, des privilèges et de la mise en suspens pour des raisons juridiques. Les auteurs terminent en faisant des recommandations sur des politiques pouvant être mises en place avant qu'un incident se produise et des actions pouvant être prises immédiatement après un incident grave.
\end{abstract}

\section{TABLE OF CONTENTS}

I. INTRODUCTION . . . . . . . . . . . . . . . . . . . . . . 388

II. PRIME CONTRACTOR RESPONSIBILITY $\ldots \ldots \ldots \ldots \ldots \ldots \ldots \ldots \ldots \ldots . \ldots \ldots$

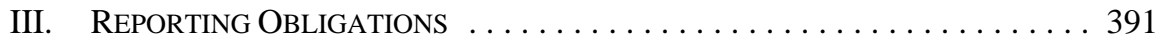

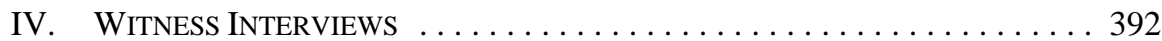

V. Privacy of Medical ReCords $\ldots \ldots \ldots \ldots \ldots \ldots \ldots \ldots \ldots \ldots \ldots$

A. Hospital and Medical Records . . . . . . . . . . . . . . . . 393

B. AUTOPSY REPORTS . . . . . . . . . . . . . . . . . . . . . . . 394

C. CAN AN EMPLOYER OBTAin THE RESUlts of AN

Autopsy that is PERFORMEd? . . . . . . . . . . . . . . . . . . . . . 397

VI. Drug and Alcohol Testing . . . . . . . . . . . . . . . . . . . . 399

A. Testing of AN EMPLOYeE $\ldots \ldots \ldots \ldots$. . . . . . . . . . . . . . 399

B. REQUIRING TESTS OF A CONTRACTOR'S OR

SUBCONTRACTOR'S WORKER $\ldots \ldots \ldots \ldots \ldots \ldots \ldots . \ldots . \ldots . \ldots 4$

C. CONDUCt OF Post-InCident Testing When

THERE IS EXPRESS OR IMPLIED CONSENT $\ldots \ldots \ldots \ldots \ldots \ldots .402$

D. WHEN THERE IS NO EXPRESS OR IMPLIED CONSENT $\ldots \ldots \ldots \ldots 403$

VII. PRivileged CommunicAtions, Documents, ANd Materials . . . . . . . 404

A. Privilege - What is It? . . . . . . . . . . . . . . . . . . . 404

B. Solicitor-Client Privilege (Advice Privilege) $\ldots \ldots \ldots \ldots 405$

C. Litigation Privilege $\ldots \ldots \ldots \ldots \ldots \ldots \ldots \ldots \ldots \ldots . \ldots \ldots$

D. PRIVILEGE APPLIED TO INCIDENT RESPONSE, INVESTIGATION, AND REPORTING $\ldots \ldots \ldots \ldots \ldots \ldots \ldots \ldots . \ldots 40 . \ldots \ldots$

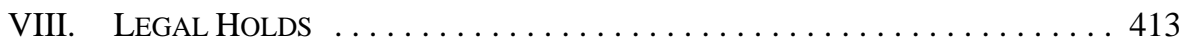

* $\quad$ Senior Counsel at Petro-Canada and a member of the Major Emergency Response Team.

** Partner with Fraser Milner Casgrain LLP, Calgary, Alberta. She would like to thank Corey Sandquist, articling student at Fraser Milner Casgrain LLP, for his assistance with this article. 

A. Statutory Duty to Retain The
SECTION 18 REPORT AND PRESERVE THE SCENE . . . . . . . . . . . . 413
B. DOCUMENTS AND MATERIALS TO DEFEND AN OCCUPATIONAL
HEALTH AND SAFETY CHARGE $\ldots \ldots \ldots \ldots \ldots \ldots \ldots \ldots \ldots$
C. PRESERVATION OF EVIDENCE: SPOLIATION AND
NEGLIGENT DESTRUCTION OF EVIDENCE . . . . . . . . . . . . . . . . . . . 414
IX. SySTEMS AND PROCEDURES TO HAVE IN

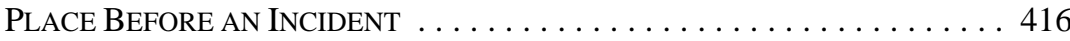

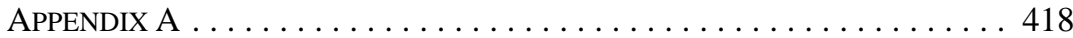

\section{INTRODUCTION}

Alberta Employment and Immigration, the department that oversees Workplace Health and Safety, reported that, in 2008, 22 Alberta companies were fined more than \$5 million for health and safety violations. Not only were more charges laid in 2008 than ever before, but the maximum amount of fines levied more than tripled from the previous year. ${ }^{1}$ Additionally, prosecutions arose from all types of incidents; even incidents where there was no injury, fatality, or property damage, but a breach of the legislation was alleged to have occurred.

We are in a new era of concerted enforcement of occupational health and safety legislation and with that enforcement there are new challenges for those dealing with incident investigations on the front line. On the one hand, there is an emphasis on being as collaborative as possible with regulators, while at the same time there can be serious consequences of a conviction under the Occupational Health and Safety Act, ${ }^{2}$ both financially and to reputation.

This article is written with in-house counsel in mind. There are a variety of resources available for occupational health and safety professionals, ${ }^{3}$ but little material prepared for inhouse counsel in the oil and gas industry who need to address a multitude of urgent and critical issues in the aftermath of a serious incident. Given the restrictions on length, this article is by no means exhaustive, but does address some of the issues that in-house counsel will be required to address on short notice.

We have restricted the article to a consideration of the responses to an incident in the context of occupational health and safety. Depending on the type of incident, there may be other significant reporting and investigation requirements (such as in the case of environmental or regulatory obligations). These other areas are beyond the scope of this article.

$1 \quad$ Employment and Immigration, News Release, “Alberta imposes record penalties for Occupational Health and Safety violations” (29 December 2008), online: Government of Alberta <http://alberta.ca/ ACN/200812/2504564F51EC2-C6E3-1504-8E7CEDF0DBAB5A9E.html>.

R.S.A. 2000, c. O-2 [OH\&S Act].

See e.g. Construction Owners Association of Alberta (COAA), Workplace Health and Safety Serious Incident Reporting and Investigation Guideline (Edmonton: Constuction Owners Association of Alberta) [forthcoming]; Norman A. Keith \& Adam A. Neave, A Practical Guide to Occupational Health and Safety and Workers' Compensation Compliance in Alberta (Aurora: Canada Law Book, 2007); Norm Keith \& Alisa Jane Wiggins, Alcohol and Drugs in the Canadian Workplace: An Employer's Guide to the Law, Prevention and Management of Substance Abuse (Markham: LexisNexis Canada, 2008). 
Additionally, this article does not address the issue of criminal prosecution under Bill C45. ${ }^{4}$ The legal ramifications and roles of the parties in criminal investigations are remarkably different and require consideration beyond that provided in this article. ${ }^{5}$

Although provinces across Canada have enacted occupational health and safety legislation, this article focuses on the statutory regime in Alberta.

\section{Prime Contractor Responsibility}

In 1994, the OH\&S Act was amended to introduce the concept of "prime contractor.” The prime contractor designation is applicable when there are two or more "employers" on a site at the same time. ${ }^{6}$ There are very few significant undertakings in the province of Alberta where there are not at least two employers on the site at the same time and the prime contractor obligations will apply to almost all oil and gas projects (whether drilling, constructing, laying pipe, or operating or maintaining facilities). Merely having one contractor and the owner's personnel on-site at the same time will trigger the prime contractor provisions of the $O H \& S$ Act.

The role of prime contractor was introduced for the purpose of increasing the success rate of prosecutions under the $O H \& S$ Act, which were getting bogged down because multiple parties would blame each other for safety failures on the site.

On a multi-party site, the prime contractor designation ensures that one party is ultimately responsible for safety. This does not mean that the prime contractor is responsible for taking all safety actions, but the prime contractor is responsible for making sure that all safety requirements are met by the appropriate party. For instance, the prime contractor need not organize site safety meetings, but must ensure that the appropriate safety meetings are held by the applicable parties.

With the delegation of prime contractor, one party is responsible for overall health and safety, regardless of the actions of others on-site. This does not mean that employees and employers will not be charged if there is a breach of the OH\&S Act, the Occupational Health and Safety Regulation, ${ }^{7}$ or the Occupational Health and Safety Code, ${ }^{8}$ but it may mean that the prime contractor is charged along with others. (assented to 7 November 2003), S.C. 2003, c. 21 (see in particular the amendments to the Criminal Code, R.S.C. 1985 , c. C-46, s. 217.1).

$5 \quad$ See Cheryl A. Edwards \& Ryan J. Conlin, Corporate and Organizational Liability for OH\&S Under Bill C-45: A CLV Special Report (Toronto: Carswell, 2005).

$6 \quad$ OH\&S Act, supra note 2, s. 3(1) ("Every work site must have a prime contractor if there are 2 or more employers involved in work at the work site at the same time").

$7 \quad$ Alta. Reg. 62/2003 [OH\&S Regulation].

8 Occupational Health and Safety Code 2009 Order, Alta. Reg. 87/2009. 
Without delegation, the role of prime contractor defaults to the "owner of the work site."9 The role of prime contractor may be delegated to another party, ${ }^{10}$ but making that designation is part of the strategic planning for the project as serious consequences flow from that decision. ${ }^{11}$

Whether or not the role of prime contractor is delegated, the vast majority of oil and gas projects will have a prime contractor. In this article, the roles and responsibilities pursuant to the $O H \& S$ Act are discussed generically in the context of the prime contractor notwithstanding that these obligations would fall to the owner of the work site in the event no delegation of the role of prime contractor has been made.

Offences under the $O H \& S$ Act are ones of strict liability and the defence of due diligence is available to any accused. To avoid charges, or to successfully defend charges under the $O H \& S$ Act, the prime contractor must show that it "exercised all reasonable care by establishing a proper system to prevent the commission of the offence" and that it "took reasonable steps to ensure the effective operation of its system and supervised its operation." ${ }^{12}$ In addition, to avoid prosecution, these actions need to be documented. ${ }^{13}$

OH\&S Act, supra note 2, s. 3(2).

While the Act does not specify that a written agreement must be entered into and states only that "an agreement" must be entered into, s. 8 of the $O H \& S$ Regulation provides that any required procedures must be in writing and, in any event, it would not be prudent to have anything but a written agreement to delegate the role of prime contractor. The language used in a contract to delegate the role of prime contractor can range from simple to complex and depends on the particular situation. For example, the COAA incorporates a simple clause in its standard form "Engineering, Procurement and Construction Contract" (2005), ss. 25.5-25.6, online: COAA <http://www.coaa.ab.ca/LinkClick.aspz?link=pdfs $\% 2$ FEPCM+Contract $\% 2$ fEPC+Contract.pdf $>$ :

Subject to Section 25.6,

[NTD: Insert Owner, Contractor or the name of the

Other Contractor, as applicable] shall be the "prime contractor", as that term is defined in the

Occupational Health and Safety Act (Alberta), for the Work as stipulated in the Owner's

Requirements.

Where the Contractor is stipulated as the "prime contractor" for the purposes of the Occupational

Health and Safety Act (Alberta) in the Owner's Requirements, the Owner may take over the role

of "prime contractor" at any time as may be stipulated in the Owner's Requirements.

11 The party implementing and ensuring the safety procedures are in place is usually the best party to take on the role of prime contractor. Where the role is delegated, the owner must ensure that the party taking on the role has the adequate resources to implement a safety program in a manner that meets the minimum requirements of the law and, presumably, the owner's own safety standards. Further, contractual terms that mandate consultation with, and require reporting to, the owner of the work site in the event of an incident should be included in agreement between the parties.

12 R. v. Cargill Ltd., 2000 ABPC 208, 283 A.R. 100 at para. 30, Stevenson J., quoting R. v. Sobeys, Inc., (2000), 181 N.S.R. (2d) 263 at paras. 29, 36 (S.C.) (referred to by defence counsel).

$13 \quad$ Other specific duties include: establishing and maintaining a system or process that ensures compliance with the Act, OH\&S Regulation, and Government of Alberta, Occupational Health and Safety Code 2009 (Edmonton: Alberta Queen's Printer, 2009) [OH\&S Code]; ensuring that first aid services, equipment, and supplies required by the OH\&S Code are available at the work site; and ensuring that the equipment erected or installed by or on behalf of the prime contractor complies with the requirements of the $O H \& S$ Code as if the prime contractor was the employer (see Employment and Immigration, Bulletin, LI018, "The Prime Contractor" (August 2008), online: Government of Alberta $<$ http://employment.alberta.ca/ documents/WHS/WHS-PUB_li018.pdf>). 


\section{REPORTING OBLIGATIONS}

One of the obligations of the prime contractor is to report serious injuries or accidents to Alberta Workplace Health and Safety. ${ }^{14}$ The types of injuries and accidents that must be reported are set out in s. $18(2)$ of the OH\&S Act: ${ }^{15}$

(a) an injury or accident that results in death,

(b) an injury or accident that results in a [worker] being admitted to a hospital for more than 2 days,

(c) an unplanned or uncontrolled explosion, fire or flood that causes a serious injury or that has the potential of causing a serious injury,

(d) the collapse or upset of a crane, derrick or hoist, or

(e) the collapse or failure of any component of a building or structure necessary for the structural integrity of the building or structure. ${ }^{16}$

In relation to a serious injury or accident referred to in s. 18(2) of the $O H \& S$ Act, or any other serious injury accident that has the potential of causing serious injury, ss. 18(3) and 18(4) of the $O H \& S$ Act require the prime contractor to:

(a) carry out an investigation;

(b) prepare a report that includes the circumstances of the incident and the corrective action taken, if any, to prevent a recurrence of the incident;

(c) make the report available for inspection by a Workplace Health and Safety officer; and

(d) retain the report for two years after the incident.

Section 18(5) of the $O H \& S$ Act states that a report prepared pursuant to s. 18(3) of the $O H \& S$ Act "is not admissible as evidence for any purpose in a trial arising out of the serious injury or accident, an investigation or public inquiry under the Fatality Inquiries Act or any other action as defined in the Alberta Evidence Act except in a prosecution for perjury or for the giving of contradictory evidence." ${ }^{17}$ However, the report will certainly factor into the consideration of the incident by the Workplace Health and Safety officers and, if applicable, the Crown prosecutor as to whether charges will be laid in relation to the incident.

OH\&S Act, supra note 2, s. 18(1).

See also OH\&S Code, supra note 13 , s. 544, which stipulates additional reporting requirements for mines.

OH\&S Act, supra note 2, s. 18(2).

Ibid., s. 18(5). 


\section{WITNESS INTERVIEWS}

Workplace Health and Safety officers have the authority to interview witnesses in relation to the incident. ${ }^{18} \mathrm{~A}$ witness can be subject to prosecution if the witness makes a false statement or knowingly gives false information to a Workplace Health and Safety officer. ${ }^{19}$

Witness statements taken by Workplace Health and Safety have similar prohibitions on their use as the report prepared by the prime contractor. ${ }^{20}$ If a witness statement is taken that may be used later in a proceeding as evidence against the party making it, for instance in a criminal charge, then the person making the statement should be first given a Miranda warning:

Hence, when the predominant purpose of the investigation is in regards to penal liability any compelled evidence obtained during this stage without the individual giving the information being chartered and cautioned or told that the evidence is no longer being [gathered] for the accident investigation, but for penal liability, would then result in an infringement of Charter rights. ${ }^{21}$

However, in the same way as reports may be used, witness statements will be used to determine whether any charges should be laid in relation to the incident. It is this concern that gives rise to the interest in having counsel present at the interviews of witnesses conducted by Workplace Health and Safety officers.

In Ebsworth, ${ }^{22}$ Workplace Health and Safety officers attended a work site where a fatality had occurred and interviewed a co-worker who witnessed the incident, Mark Ebsworth, with his employer's counsel present. Later, Ebsworth and other witnesses were told that they could only have their own counsel and not the employer's counsel in attendance at interviews. Finally, the Workplace Health and Safety officers advised Ebsworth and the other witnesses that the policy had changed and that no counsel would be permitted to attend the interviews. However, the witnesses were informed that during an interview they could ask for an adjournment to speak with counsel and it would be granted if it was "reasonable."23

A second interview, without counsel, was requested of Ebsworth. He was told that he would not be provided with copies of his original written or oral statements or be able to review them before the interview. Ebsworth brought an application seeking to have the right to have counsel present at his interview. During argument, counsel for the Crown advised that the policy had changed again and that copies of previous statements would be made available on request. Justice Verville neatly summarized his findings in the case as follows:

1. Although it may be desirable and perhaps even advantageous to permit the presence of legal counsel during an interview conducted pursuant to s. 19 of the OHS Act, [Workplace Health and Safety] has the jurisdiction to govern its procedure and to exclude the presence of legal counsel.

Ibid., s. 19.

Ibid., s. 41(3).

Ibid., s. 19(5).

Toronto (City of) v. Baillie, 2007 ONCJ 244, 74 W.C.B. (2d) 242 at para. 82.

Ebsworth v. Alberta (Human Resources and Employment), 2005 ABQB 976, 396 A.R. 345 [Ebsworth]. Ibid. at para. 14. 
2. The policy of prohibiting witnesses from having legal counsel present during an investigative interview pursuant to section 19 of the OHS Act is not contrary to the Charter.

3. If the issue of whether [Ebsworth] is entitled to copies of his oral and written statements under FOIPPA continues to be germane it is my opinion that [Ebsworth] should first apply to the Alberta Commissioner, and if unhappy with his decision seek judicial review. ${ }^{24}$

\section{PRivacy Of Medical Records}

\section{A. Hospital AND MEdicAl REcoRdS}

In certain cases, the prime contractor or employer might suspect that a medical condition might be relevant to an incident, however, an employer or owner of the work site where the incident occurred does not have an inherent right to see a worker's medical reports. Access to health information is governed by the Health Information Act. ${ }^{25}$

While hospitals are a public body, the Freedom of Information and Protection of Privacy $A c t^{26}$ does not apply to the disclosure of medical records as FOIPP specifically states that a request for information to which the Health Information Act applies is deemed to be a request under the Health Information Act. ${ }^{27}$

Information to which the Health Information Act applies is determined by reference to the definition of "health information":

(k) "health information" means any or all of the following:

$$
\text { diagnostic, treatment and care information. }{ }^{28}
$$

In turn, “diagnostic, treatment and care information” is defined as:

(i) “diagnostic, treatment and care information” means information about any of the following:

(i) the physical and mental health of an individual;

(ii) a health service provided to an individual;

(iii) the donation by an individual of a body part or bodily substance, including information derived from the testing or examination of a body part or bodily substance;

Ibid. at para. 69.

R.S.A. 2000, c. H-5.

R.S.A. 2000, c. F-25 [FOIPP].

Ibid., s. 15.1 .

Health Information Act, supra note 25, s. 1(1)(k). 
and includes any other information about an individual that is collected when a health service is provided to the individual, but does not include information that is not written, photographed, recorded or stored in some manner in a record. ${ }^{29}$

The Health Information Act also provides that, unless a provision of another act specifically overrides the Health Information Act, the Health Information Act will govern. ${ }^{30}$ Treatment in a hospital post-incident would fall under this statute.

\section{WHEN EXPRESS OR IMPLIED CONSENT IS PRESENT}

The Health Information Act provides that when consent has been given by the individual whose health information is being sought, then the custodian of that information can disclose it to the requesting party. Only express consent, written or electronic, will be sufficient for an employer to obtain medical reports. ${ }^{31}$

The statutory requirements for consent would likely pre-empt an employer from arguing that implied consent is sufficient to disclose the information under the Health Information Act as implied consent would typically not be in writing and would not contain all of the required information. However, it is open to an employer to obtain a consent in the terms of an employment contract where such consent is only triggered upon the happening of an incident causing serious injury or death.

\section{WHEN NO EXPRESS OR IMPLIED CONSENT IS PRESENT}

The Health Information Act provides that disclosure of diagnostic, treatment, and care information may be done in certain circumstances where consent has not been provided by the individual. ${ }^{32}$ These circumstances include disclosure for the purpose of a court proceeding or proceeding before a quasi-judicial body, or for the purposes of complying with a subpoena, warrant, or order issued or granted by a court. ${ }^{33}$ An employer does not have any right to obtain the information of the employee without consent and the Health Information Act is clear that a custodian of health information may not disclose the health information of the employee without consent. ${ }^{34}$

\section{B. AutOpSY REPORTS}

Whether an autopsy will be performed is governed by the surrounding circumstances of the death. Autopsies are governed by the Fatality Inquiries Act, ${ }^{35}$ which requires notification by any person aware of the circumstances to a medical examiner or investigator when specified circumstances surround the death. ${ }^{36}$ Deaths that occur as the result of an accident

Ibid., s. 1(1)(i).

Ibid., s. 4.

Ibid., s. 34(2); see also Health Information Regulation, Alta. Reg. 70/2001, s. 6.

Health Information Act, ibid., s. 35.

Ibid., ss. 35(1)(h) (for an action to which the custodian of the information is party), 35(1)(i) (for broader applications).

Ibid., s. 31.

R.S.A. 2000, c. F-9.

Ibid., s. 10. 
or deaths that are due to any injury sustained by the deceased as a direct result of the deceased's employment or occupation, or in the course of one or more of the deceased's former employments or occupations, are included in the deaths that require notification. ${ }^{37}$ The Fatality Inquiries Act further requires that the medical examiner who receives notification shall investigate the death and, where possible, establish the circumstances under which the death occurred, the cause of the death, and the manner of death. The autopsy will only be performed if the medical examiner exercises his or her discretion and authorizes the autopsy. ${ }^{38}$

An employer does not have any specific rights to request that an autopsy be performed. However, the Fatality Inquiries Act makes an investigation mandatory in circumstances where the cause of death was an accident. The wording of the Fatality Inquiries Act indicates that the employment situation would require, at the least, an investigation. ${ }^{39}$ Section 10 provides:

(1) Any person having knowledge or reason to believe that a person has died under any of the circumstances referred to in subsection (2) or section 11,12 or 13 shall immediately notify a medical examiner or an investigator.

(2) Deaths that occur under any of the following circumstances require notification under subsection (1):

(c) deaths that occur as the result of violence, accident or suicide;

(j) deaths that are due to

(i) any disease or ill-health contracted or incurred by the deceased,

(ii) any injury sustained by the deceased, or

(iii) any toxic substance introduced into the deceased,

as a direct result of the deceased's employment or occupation or in the course of one or more of the deceased's former employments or occupations. ${ }^{40}$

The medical examiner also has a positive obligation to, where possible, establish the circumstances under which the death occurred, the cause of death, and the manner of death. ${ }^{41}$ It is also open to the Chief Medical Examiner ${ }^{42}$ to direct that an autopsy be performed. ${ }^{43}$

Ibid., ss. 10(2)(c), (j).

Ibid., ss. 19(1), 25(1).

Ibid., s. 20.

Ibid., s. 10

Ibid., s. 19(1).

The Court in R. v. Rhyason, 2006 ABQB 2, 394 A.R. 94 [Rhyason], summarized the role of medical examiners at para. 18:

The Fatality Inquiries Act ... states that the Chief Medical Examiner is an officer appointed by the

Lieutenant-Governor (Section 5(1)) who supervises medical examiners (Section 5(4)). A medical 
The Fatality Inquiries Act sets out when a Public Fatality Inquiry can be held. ${ }^{44}$ The Public Fatality Inquiry is heard before a Provincial Court Judge. The judge renders a report containing:

(a) the identity of the deceased;

(b) the date, time and place of death;

(c) the circumstances under which the death occurred;

(d) the cause of death;

(e) the manner of death. ${ }^{45}$

An autopsy may be required as part of this inquiry and, if it is, it becomes part of public record.

The Office of the Chief Medical Examiner suggests that Public Fatality Inquiries will most often be held in the event of accidental deaths, especially where the death may have been preventable. $^{46}$

There is some suggestion in case law that where it is in the interest of public safety or to fully understand the circumstances surrounding a death, there could be a compelling argument that an autopsy would be required. In Bowness, ${ }^{47}$ the Court cited Faber ${ }^{48}$ where the Supreme Court of Canada indicated that a Public Fatality Inquiry is held for the purpose of exposing the circumstances of a death. ${ }^{49}$ While this discussion was in the context of a Public Fatality Inquiry, it illustrates the emphasis on the importance of learning what caused a fatality and what the circumstances are surrounding that fatality. An employer could argue that the autopsy would be required to determine whether the employee was influenced by drugs or alcohol.

While an employer or owner could request a Public Fatality Inquiry be performed by the Chief Medical Examiner, this is not an easy request to have fulfilled. However, it would result in the performance of an autopsy that might not otherwise be undertaken. If a Public Fatality Inquiry is performed, then this information becomes public knowledge and available to the employer or owner. However, in the context of a workplace incident, it is unlikely that the employer or owner would want the incident reviewed in such a public proceeding.

examiner has a duty to investigate the death and make a report of the investigation to the Chief Medical Examiner (Section 19(1) and (3)). The Chief Medical Examiner has the power to authorize an autopsy (Section 20(b)), as does the medical examiner (Section 25(1)). Fatality Inquiries Act, supra note 35, s. 20.

Ibid., s. 35.

Ibid., s. 53(1).

"Public Fatality Inquiries: Who Calls a Public Fatality Inquiry?” online: Government of Alberta <http:// www.justice.gov.ab.ca/fatality/public_fatality.aspx?id=473>. Re Bowness, 2002 ABPC 207, 352 A.R. 13 [Bowness].

R. v. Faber, [1976] 2 S.C.R. 9 [Faber].

Bowness, supra note 47 at para. 13. 


\section{CAN AN EMPLOYER OBTAIN THE RESULTS OF AN Autopsy THAT IS PERFoRMED?}

The Fatality Inquiries Act provides that all reports, certificates, and records made by any person under the Fatality Inquiries Act are the property of the government and will not be released without the permission of the Chief Medical Examiner. ${ }^{50}$ In Bowness, the Court found that the statute is straightforward; the only time documents will not be the property of the government is when they are produced for a Public Fatality Inquiry. ${ }^{51}$

The Fatality Inquiries Regulation ${ }^{52}$ provides that the Chief Medical Examiner must produce an autopsy summary report to any person who requests the report and whom the Chief Medical Examiner considers to be an interested party. ${ }^{53}$ The Court in Rhyason interpreted this provision and stated that it "clearly reserves to the Medical Examiner the right to decide whether the person or government agency is an 'interested party.,"54 The Court stated that the Fatality Inquiries Regulation clearly envisions the medical examiner as an autonomous custodian of the information derived from its investigation in any autopsy performed. ${ }^{55}$ It would be open to an employer to argue that it is an "interested party." However, the production or disclosure of an autopsy performed on the employee will otherwise be governed by FOIPP because autopsy records are the property of the government. $^{56}$

Further, the Alberta Information and Privacy Commissioner (the Commissioner) considered the issue of whether an autopsy report should be produced on the basis that it was in the public interest in Order 2000-012. ${ }^{57}$ In that case it was clear that the office of the Chief Medical Examiner was a public body and its information was governed by FOIPP. ${ }^{58}$ The Commissioner also endorsed and applied an Ontario ruling that held that "post-mortem forensic tests relate to the medical condition of a deceased individual at the time of death, and so fall within the scope of 'personal information.",59 Thus, autopsy reports are considered personal information and are governed by FOIPP rather than other statutes dealing with personal medical and health information.

FOIPP provides that a public body may disclose personal information if there has been consent, the disclosure would not be an unreasonable invasion of privacy, or for use in a judicial proceeding or to comply with a court order or subpoena. ${ }^{60}$ FOIPP controls the disclosure of personal information, including autopsy reports, in s. 17:

Fatality Inquiries Act, supra note 35, s. 30.

Bowness, supra note 47 at para. 40.

Alta. Reg. 65/2000.

Ibid., s. 12.

Rhyason, supra note 42 at para. 27.

Ibid.

Fatality Inquiries Act, supra note 35, s. 30(1).

Alberta, Information and Privacy Commissioner, Order 2000-012 (23 August 2000) [AIPC Order 2000-

012].

Ibid. at para. 3 .

Ibid. at para. 15.

FOIPP, supra note 26, s. 40. 
(1) The head of a public body must refuse to disclose personal information to an applicant if the disclosure would be an unreasonable invasion of a third party’s personal privacy.

(4) A disclosure of personal information is presumed to be an unreasonable invasion of a third party's personal privacy if

(a) the personal information relates to a medical, psychiatric or psychological history, diagnosis, condition, treatment or evaluation. ${ }^{61}$

FOIPP allows for disclosure of information if consent has been given. ${ }^{62}$ The Freedom of Information and Protection of Privacy Regulation ${ }^{63}$ provides:

7(2) The consent of an individual to a public body's using or disclosing any of the individual's personal information under section 39(1)(b) or 40(1)(d) of the Act

(a) must meet the requirements of subsection (4), (5) or (6), and

(b) must specify to whom the personal information may be disclosed and how the personal information may be used.

(3) The consent or request of a third party under section 17(2)(a) of the Act must meet the requirements of subsection (4), (5) or (6).

(4) For the purposes of this section, a consent in writing is valid if it is signed by the person who is giving the consent. ${ }^{64}$

The effect of FOIPP is that the employer can obtain the autopsy report pursuant to FOIPP if:

(1) it can be demonstrated that the disclosure by the public body would not be an unreasonable invasion of privacy; or

(2) consent has been provided by the deceased's estate.

This first method is difficult to demonstrate. There is a prima facie presumption against the employer that it would be an unreasonable invasion of the deceased's privacy. ${ }^{65}$ The second method would only be available if the consent was in accordance with the statutory provisions mentioned above.

Ibid., s. 17.

Ibid., ss. 17(2)(a), 40(1)(d).

Alta. Reg. 186/2008.

Ibid., s. 7. Section 7(5) provides that electronic disclosure is sufficient and s. 7(6) provides that oral consent is valid as well, as long as certain criteria are met.

FOIPP, supra note 26, s. 17(4); AIPC Order 2000-012, supra note 57 at para. 20. 


\section{Drug AND Alcohol Testing}

Setting aside the multitude of issues dealing with whether different elements of a drug and alcohol policy are valid, this section discusses the application of a drug and alcohol policy after an incident or near miss has occurred. ${ }^{6}$ For the sake of simplicity, these two scenarios will be referred to generically as "incidents."

Post-incident, the employer or owner of the work site may want to ensure that a drug and alcohol test is carried out in accordance with the applicable work site testing policy. As a practical matter, this can often be more difficult than it seems as the testing is time sensitive and, in some instances, co-operation from the various parties may be lacking or there may be access issues that make testing much more challenging.

Although a contractor may be under a contractual obligation to comply with a drug and alcohol policy, if the contractor's employee is involved in an incident the contractor may see no value in providing assistance to the prime contractor to obtain a sample in a manner that allows the testing to be valid or take place at all. Consider what the sanctions are in your drug and alcohol policy for contractors who fail to assist, or obstruct, the process for gathering samples in the appropriate time frames.

\section{A. Testing of AN EMPLOYeE}

The employer's ability to require a post-incident test is derived from express or implied consent that is created by virtue of the employer-employee relationship. An employer cannot physically force testing if a worker or employee revokes consent or refuses to give it. If an employee was to withdraw the consent post-incident, the applicable policy should be clear that immediate termination is the consequence. The jurisprudence discussing post-incident testing also recognizes that testing must be done in a timely way.

The employer derives its right to perform post-incident testing based on either express or implied consent that exists because of some sort of agreement in place. The agreement can be a unilaterally imposed policy of the owner or company. ${ }^{67}$

Several arbitrations that have dealt with situations where the issue was not whether the consent existed or whether the policy was reasonable have tended to focus on the drug and alcohol policy itself. The focus has been on what was allowed under the policy, which implies that the issue requires an examination of the extent of the consent that existed. (Policy Grievance) (2006), 157 L.A.C. (4th) 225 at para. 92 (Ontario Labour Arbitration) [Imperial]; Weyerhaeuser Co. v. Communications, Energy and Paperworkers Union, Local 447 (Roberto Grievance) (2006), 154 L.A.C. (4th) 3, (Alberta Grievance Arbitration) [Weyerhaeuser]; Alberta (Human Rights and Citizenship Commission) v. Elizabeth Metis Settlement, 2005 ABCA 173, 367 A.R. 142.

$67 \quad$ Construction Labour Relations (Alberta Assn. Operating Engineers (Provincial) Trade Division) v. International Union of Operating Engineers, Local 955 (Graham Grievance) (2004), 129 L.A.C. (4th) 1 (Alberta Grievance Arbitration) [Construction Labour Relations]; Greater Toronto Airports Authority v. Public Service Alliance of Canada, Local 0004 (2007), 90 C.L.A.S. 177 (Canada Labour Arbitration) [Toronto Airports]. 
In Construction Labour Relations, the employer unilaterally implemented the Alcohol and Drug Guidelines and Work Rule. ${ }^{68}$ Subsequent to that implementation, an employee, while using a spring-loaded knife to cut a rope, cut his hand and required five stitches. The employer asked the employee to take a drug and alcohol test as it was required under the policy. The employee refused and was immediately terminated. The Arbitration Board focused on the language of the policy in attempting to determine the scope and application of the drug and alcohol policy. The Arbitration Board found that the incident was captured by the policy and it was not open to the employee to refuse the test. ${ }^{69}$ The Arbitration Board found that consent had been given to drug testing if an event fell under the policy. The consent existed by virtue of working for the employer and continuing the employment after being given notice of the policy. Since this consent was subsequently withdrawn by the employee, the employer was within its rights to immediately terminate the employee for cause.

This conclusion was also reached in Toronto Airports, where the Board held that reasonable cause and post-incident testing of employees in safety sensitive positions was a bona fide occupational requirement. ${ }^{70}$ It is also recognized that employers are entitled to determine the cause of an incident and that they have a need to test on a timely basis. This appears to be applicable for both reasonable cause testing and post-incident testing. ${ }^{71}$

In CAW-Canada, ${ }^{72}$ an employee was driving a truck and stopped on train tracks to turn around. The truck was struck by a freight car, causing damage. The employee was ordered to take a drug test and he refused. The Arbitration Board held that the drug test does not have to actually prove impairment to be a legitimate test. Rather, post-incident testing was part of the employer's diligent exercise of its obligations in respect of safe operations in the workplace. The employer was legitimately entitled to know the reasons for an incident, and drug and alcohol testing is one means of determining that cause. ${ }^{73}$

Similarly, in Dupont, the arbitrator found that an employer can engage in reasonable cause testing for employees in safety sensitive positions. ${ }^{74}$ Construction Labour Relations recognized that an employer needs to complete such testing in a timely fashion in order to carry out its purpose of determining potential causes for an incident. ${ }^{75}$

Construction Owners Association of Alberta, Canadian Model for Providing a Safe Workplace: A Best Practice of the Construction Owners Association of Alberta - Alcohol and Drug Guidelines and Work Rule (Edmonton: Construction Owners Association of Alberta, 2005). Construction Labour Relations, supra note 67 at para. 66. Toronto Airports, supra note 67 at para. 293; Dupont Canada v. Communications, Energy Paperworkers Union of Canada, Local 28-0 (Drug and Alcohol Policy Grievance) (2002), 105 L.A.C. (4th) 399 at para. 22 (Ontario Labour Arbitration) (Arbitrator: P.C. Picher) [Dupont].

Fording Coal Ltd. v. United Steelworkers of America, Local 7884 (Olson Grievance) (2002), 112 L.A.C. (4th) 141 (British Columbia Collective Agreement Arbitration) [Fording]; Elk Valley Coal Corp. v. United Steelworkers of America, Local 7884 (2003), 121 L.A.C. (4th) 280 (British Columbia Collective Agreement Arbitration) [Elk Valley]; Construction Labour Relations, supra note 67.

Canadian National Railway v. National Automobile, Aerospace, Transportation and General Workers Union of Canada (CAW-Canada) (2000), 95 L.A.C. (4th) 341 (Canada Labour Arbitration) [CAWCanada].

Ibid. at para. 194.

Dupont, supra note 70 at para. 16 (citing CAW-Canada in support); see also Elk Valley, supra note 71 at para. 24.

Construction Labour Relations, supra note 67 at para. 60. 
The Arbitration Board in Fording dealt with an employee who backed a large truck into a steam bay door. The employee was subsequently ordered to take a drug and alcohol test pursuant to the employer's policies. The Arbitration Board held that employees working in an open pit mine are working in a safety sensitive environment. "For cause" testing is appropriate and privacy rights are outweighed by the safety concerns in this instance. The Arbitration Board also expressed concern over obtaining reliable evidence, suggesting a delay in testing may defeat the purpose of drug and alcohol testing. ${ }^{76}$

\section{B. REQUIRING TESTS OF A CONTRACTOR'S OR SUBCONTRACTOR'S WORKER}

When the employer-employee relationship exists, there is the opportunity to put in place an express or implied agreement that an employee must undergo for cause testing. However, in the owner-worker relationship, there may not be a contract between those parties. Absent the contract, the question will be whether there is implied consent to permit forced testing.

The owner-worker situations commonly deal with an owner who has workers on its site who work for a contractor or subcontractor. There may be an agreement in place between the owner and the contractor or subcontractor regarding a drug and alcohol testing policy.

In Finning, ${ }^{77}$ an owner adopted a drug and alcohol testing policy that required all employees of subcontractors to be tested for drug use before site access was allowed. The policy specifically required drug and alcohol testing when site access was being granted, reasonable grounds existed, or after a significant incident. ${ }^{78}$ The Arbitration Board dismissed a grievance brought against the employer, which claimed that adhering to the owner's testing policies was a violation of the collective agreement.

The Arbitration Board in Finning found that the employer can only be in a breach of the collective agreement when it takes its own actions, but will not be in breach on the basis of the owner's actions. ${ }^{79}$ Further, the workers were either impliedly or expressly agreeing to being subjected to the drug and alcohol testing by virtue of their working on the site. ${ }^{80}$ It is important to note that in this instance the workers were given notice of the drug and alcohol testing policies. If there had been no notice and no express or implied consent, then it is doubtful that the owner would have been able to perform or demand any post-incident testing. ${ }^{81}$

In Construction Labour Relations, the worker had been dispatched by the union at the request of the owner of the work site. After the worker refused to take the mandatory drug and alcohol test post-incident, he was immediately dismissed. The drug and alcohol test was determined to be a reasonable request when drugs or alcohol were a possible cause. ${ }^{82}$ There

\footnotetext{
Fording, supra note 71 at paras. 119, 134.

Finning (Canada) v. International Assn. of Machinists and Aerospace Workers Local Lodge 99 (2005), 136 L.A.C. (4th) 129 (Alberta Grievance Arbitration) [Finning].

Ibid. at para. 23.

Ibid. at para. 98 .

Ibid. at para. 81 .

See United Assn. of Journeymen and Apprentices of the Plumbing and Pipefitting Industry of the United States and Canada, Local 488 v. Bantrel Constructors, 2009 ABCA 84, 448 A.R. 194.

Construction Labour Relations, supra note 67 at paras. 64-65.
} 
was no indication in Construction Labour Relations that the worker had not consented to the policy by virtue of being dispatched by the union.

\section{Conduct of Post-Incident Testing When There IS EXPRESS OR IMPLIED CONSENT}

An employer or owner can order for cause testing with threat of dismissal for noncompliance. ${ }^{83}$ However, the post-incident testing must be performed in a dignified manner. In Weyerhaeuser, two separate grievances were brought by employees who were subjected to post-incident drug and alcohol testing.

The first grievance involved a female employee who was required to go in a locked vehicle to a hotel. Upon arriving, she described the room as containing a number of men, none of whom looked to be professionals, and smelling of stale beer. The employee was told she could not wash her hands or run any water until she provided a urine sample, and was told to go into the bathroom to do so. The employee was also told that the individuals administering the test could wait for hours, if required. The second grievance involved a male employee who was subjected to similar circumstances.

The Arbitration Board in Weyerhaeuser indicated that alcohol and drug testing requires a balancing of interests between an employer's need to know the cause of an incident and the employee's rights to dignity and privacy. ${ }^{84}$ The Arbitration Board found that there is no "bright line" test and the exercise of judgment is required in every situation. ${ }^{85}$ This decision also made it clear that the testing must be carried out in a reasonable manner, in a suitable location, and performed by a qualified medical professional. ${ }^{86}$ The Arbitration Board allowed the two grievances in this instance, stating that non-compliance with an unreasonable testing procedure is a valid objection $;^{87}$ it was not open to the employer to infringe on the privacy rights of employees in a demeaning and undignified fashion.

An employer must exercise discretion every time to assess whether there was a reason for the incident and determine whether it is a possibility that drugs or alcohol were a factor. In Construction Labour Relations, the Arbitration Board found that once an incident has occurred, an employer is making a reasonable request for a drug and alcohol test when drugs and alcohol could be a potential cause. ${ }^{88}$ Similarly, the Arbitration Board in Elk Valley held that a foreman was justified in requiring a drug and alcohol test after an employee of an open pit mine skidded into a pile of rocks. Even though it was icy, the Arbitration Board held that drugs or alcohol could be a possible cause, and that was sufficient justification for requiring the test. ${ }^{89}$ The Arbitration Board went on to indicate that the test for an employer to be justified in drug and alcohol testing when investigating a safety event is lax. ${ }^{90}$ 


\section{WHEN THERE IS NO EXPRESS OR IMPLIED CONSENT}

When there is no express or implied consent, the only available option for the owner or employer is to apply to the Court under "Part 30: Special Application to the Court" of the Alberta Rules of Court. ${ }^{91}$ If authority of the Alberta Court of Queen's Bench is not obtained for the gathering of a sample and an owner or employer forces an alcohol or drug test, or demands an employee's bodily tissues and fluids, the enforcement or demand would be a violation of that employee's Canadian Charter of Rights and Freedoms ${ }^{92}$ rights pursuant to s. $8 .{ }^{93}$

In St. Peter's, ${ }^{94}$ the Arbitration Board dealt with the issue of an employer who wanted to implement mandatory flu vaccinations for all employees. If the employee refused and an outbreak occurred, the employee would be sent home without pay for the duration of the outbreak. The facility where the employees worked was a chronic care geriatric facility. The policy was being implemented unilaterally and without legislative support. There was a means of implementing policies under the governing legislation. The issue centered around whether forced medical treatment by an employer was justified or allowed.

The Arbitration Board in St. Peter's held that employees do not lose their right to privacy and integrity of the person by virtue of being employed.$^{95}$ Employers do not have an inherent right to subject the employees to physical examinations. Either consent must be present, or there must be some other principle of law that grants the right. The Arbitration Board went on to cite Morgentaler, ${ }^{96}$ in which the Supreme Court of Canada said:

The law has long recognized that the human body ought to be protected from interference by others. At common law, for example, any medical procedure carried out on a person without that person's consent is an assault. Only in emergency circumstances does the law allow others to make decisions of this nature. ${ }^{97}$

The Arbitration Board in St. Peter's indicated that when there is no consent given by the employee, the principles in Morgentaler are directly applicable. Enforced medical treatment or medical examinations will be an assault if there is no consent. ${ }^{98}$

In Imperial, the Arbitration Board made a similar statement regarding an employer attempting to force an employee to take a drug test. The Board stated that, absent consent, an employer cannot assert a right to force a medical or physical test or examination. ${ }^{99}$ The Board stated that the forcing of a test would be trespass and is analogous to a police investigation; if the government and police are unable to force testing, then it is not open for

$91 \quad$ Alta. Reg. 390/1968, rr. 394-95.

Part I of the Constitution Act, 1982, being Schedule B to the Canada Act 1982 (U.K.), 1982, c. 11.

See e.g. R. v. Dyment, [1988] 2 S.C.R. 417.

St. Peter's Health System v. Canadian Union of Public Employees, Local 778 (Flu Vaccination Grievance) (2002), 106 L.A.C. (4th) 170 (Ontario Labour Arbitration) [St. Peter's].

Ibid. at para. 14, citing Canada Post v. Canadian Union of Postal Workers (1988), 34 L.A.C. (3d) 392

(Canada Labour Arbitration).

R. v. Morgentaler, [1988] 1 S.C.R. 30 [Morgentaler].

Ibid. at para. 16.

St. Peter's, supra note 94 at para. 67.

Imperial, supra note 66 at para. 115. 
an employer to force testing by virtue of the employer-employee relationship. ${ }^{100}$ Testing for cause would be acceptable if there is an agreement in place. ${ }^{101}$

It should be noted that the employer does have some limited ability to invade on employee privacy. In Chinook Health Region, ${ }^{102}$ an employer implemented a mandatory flu vaccine policy. This was upheld as being acceptable and this situation was distinguished from that in St. Peter's. In Chinook Health Region, the policy only affected the employees who were providing continuous care for long-term residents. The employees were also allowed to use banked or holiday time while an outbreak occurred. There was an expression of very strong concern for the particular patients being exposed to any sort of infections.

The Arbitration Board in Canada Safeway, ${ }^{103}$ upheld an employer's right to implement a biometric scanning device for timekeeping purposes. While the scanning did collect personal information and invaded privacy, the Board held that a proportionality approach must be considered; the scanning was not intrusive and served a legitimate purpose. ${ }^{104}$

The Chinook Health Region and Canada Safeway examples clearly fall short of providing support to an argument that the employer is able to extend its limited ability to infringe on privacy rights to forced medical testing.

\section{Privileged Communications, Documents, AND Materials}

During initial incident response and the events after, clients are often concerned about solicitor-client privilege. They know that it is a concept about which they should be concerned. However, all too often clients do not have a grasp on any more than a vague concept of what it is. Misunderstandings abound, leading to missed opportunities to legitimately protect legal advice and materials prepared in contemplation of litigation. It is, therefore, important for counsel to make sure they have a solid understanding of the law on privilege and the nuances that will determine if communications and materials may be protected and how to establish that protection.

\section{A. Privilege - What is It?}

From its origins in evidentiary rules, the legal concept of privilege has evolved and is now a rule of substantive law. ${ }^{105}$ There now exist two types of privilege that are, in the words of Fish J. in Blank, “distinct conceptual animals and not two branches of the same tree.”106 The two animals are based on different policies and, thus, will most likely continue to evolve, each in its own distinct way.

\footnotetext{
$100 \quad$ Ibid. at paras. $115-18$.

$101 \quad$ Ibid. at para. 129.

102 Re Chinook Health Region and U.N.A., Loc. 120 (2002), 113 L.A.C. (4th) 289 (Alberta Grievance Arbitration) [Chinook Health Region].

103 Canada Safeway Ltd. v. United Food and Commercial Workers Union, Local 401 (2005), 145 L.A.C. (4th) 1 (Alberta Grievance Arbitration) [Canada Safeway].

$104 \quad$ Ibid. at para. 30.

105 See Descôteaux v. Mierzwinski, [1982]1 S.C.R. 860 at 893 [Descôteaux].

106 Blank v. Canada (Minister of Justice), 2006 SCC 39, [2006] 2 S.C.R. 319 at para. 7 [Blank].
} 
Though the "right" of privilege enjoys a broader application in modern jurisprudence, it will still only be applied after case by case and document by document analysis, ${ }^{107}$ so it is important that counsel understand the two animals well enough to invoke the correct type whenever possible.

\section{B. Solicitor-Client Privilege (Advice Privilege)}

Solicitor-client privilege, also referred to as "advice privilege"108 is based on the policy of accessibility to the law and legal advice that was established early in the English court system. ${ }^{109}$ In order for the law to have any credible foundation on which people can govern themselves and conduct their daily interactions, it must be accessible to everyone and applied uniformly. But this open, accessible system is at times, some would argue most times, complicated, even archaic. Lawyers, as individuals trained in the law, offer windows into that complex world and are the intermediaries between the law and those governed by it.

In order to be effective and useful intermediaries, lawyers must not only understand the law on the one side, they must also understand fully the individuals and their legal issues on the other. Thus, a lawyer can only be effective if there can be an open and complete dialogue between them. ${ }^{110}$ But, in order to validly invoke the privilege, certain circumstances must exist.

The privileged communication between solicitor and client must actually be entered into for the good faith purpose of seeking and providing legal advice. ${ }^{111}$ This may seem like an obvious first step, but this is an area where, in the heady storm during and after an incident, clients often misunderstand. It is not uncommon for clients to mistakenly believe that as long as the lawyer is added to a distribution list of all communications amongst team members, privilege will attach.

Lawyers should be cautious about fostering false securities about privilege protections. Communications directly with or merely including the lawyer may not be protected. Further, where a lawyer is acting as in-house counsel, r. 200(1) may apply to compel a lawyer to be examined on matters relating to their employment that are outside of the scope of legal advice dialogue, ${ }^{112}$ which creates an additional burden on counsel to be witness. ${ }^{113}$

Solosky v. The Queen, [1980] 1 S.C.R. 821 at 837 [Solosky].

Blank, supra note 106 at paras. 1-9.

Solosky, supra note 107 at 834 (discussing that Berd v. Lovelace (1577), 21 E.R. 33 (Ch.) and Dennis v. Codrington (1580), 21 E.R. 53 (Ch. D.) evidence a recognition of privileged communications between a solicitor and client as early as during the reign of Elizabeth I).

110 See Blank, supra note 106 at para. 26. The Court in Blank recognized that "the justice system depends for its vitality on full, free and frank communication between those who need legal advice and those who are best able to provide it" (at para. 26).

111 Solosky, supra note 107 at 835. See also Husky Oil Operations Ltd. v. MacKimmie Matthews, 1999 ABQB 54, 241 A.R. 115 [Husky].

112 Alberta Rules of Court, supra note 91, r. 200(1)(c).

113 See Domcan Boundary v. Enron Canada, 2005 ABQB 338, 383 A.R. 256 [Domcan Boundary]. See also Klemke Mining v. Shell Canada, 2002 ABQB 1131, 332 A.R. 154 [Klemke Mining]. 
Similarly, where a party seeks advice that has a legal component from an individual who happens to be a lawyer but is not employed as a lawyer, the communications will not be privileged. $^{114}$

Also, and this may be a more obvious point, where the communications with a lawyer are themselves not conducted in good faith and good conduct or are criminal or illegal in content, those communications will not enjoy privilege. ${ }^{115}$

Advice privilege covers only communications between the solicitor and client. It does not cover third party communications. ${ }^{116}$ This should not be construed so narrowly as to mean it will cover only one-on-one dialogue between individuals. Courts have recognized that a lawyer's client may be an organization or entity, and the legal advice is provided, in those circumstances, to more than one individual decision-maker on behalf of the corporate client. $^{117}$

Privileged communication must be intended to be confidential. ${ }^{118}$ Lawyers are always bound by their professional obligations of confidentiality, but it is the intention on the part of the client to keep the communication confidential that will colour the interaction to invoke privilege. $^{119}$

Litigation may be contemplated when the client seeks the lawyer's advice, but it is not a necessary element for advice privilege to attach. ${ }^{120}$

Courts are generally more deferent to the claimant of valid advice privilege and consider this protection more broadly than litigation privilege. ${ }^{121}$ This is largely due to the difference in policy that supports advice privilege. Solicitor-client privilege has been described as a "fundamental" right ${ }^{122}$ and is an enduring right. ${ }^{123}$

\section{Litigation Privilege}

Litigation privilege is rooted in different policy and, thus, is analyzed and applied differently than advice privilege. It provides protection over communications, documents, and materials made in preparation for anticipated or commenced litigation for policy reasons

See Husky, supra note 111. In this case, the document in question was an opinion that was prepared by an individual employed by Husky as a landman. The individual happened to also be a lawyer, but the court distinguished that she was not employed as a lawyer and that Husky merely sought her advice as a landman with that expertise and not as a lawyer with legal expertise.

Blank, supra note 106 at para. 45. See also Descôteaux, supra note 105; Solosky, supra note 107 at 835. Solosky, ibid.

See Domcan Boundary, supra note 113 at para. 19, quoting IBM Canada Limited v. Xerox of Canada Limited, [1978] 1 F.C. 513 (C.A.). See also Klemke Mining, supra note 113 (discussing, more generally, the relationship between a lawyer and a corporate client).

Solosky, supra note 107 at 835.

Descôteaux, supra note 105.

Blank, supra note 106 at paras. 59-61.

Nova, An Alberta Corp. v. Guelph Engineering (1984), 50 A.R. 199 at para. 21 (C.A.) [Nova]. See also the discussion of dominant purpose versus substantial purpose in Blank, ibid.

Solosky, supra note 107 at 839.

Descôteaux, supra note 105; Blank, supra note 106 at para. 50. 
of allowing a lawyer and client to fully investigate the legal position of the client and prepare a case for litigation. ${ }^{124}$

Litigation privilege may exist over documents, materials, or communications to which advice privilege also applies. However, it is not necessary to prove both types of privilege exist, either one is sufficient to provide protection. ${ }^{125}$

Distinguishing this protection from advice privilege, the Court in Blank held that the policy of litigation privilege aims to promote the "efficacy of the adversarial process, and not to promote the solicitor-client relationship," and to create the "zone of privacy” to allow a litigant to prepare for litigation. ${ }^{126}$

Notwithstanding this policy allowing lawyers and clients room to prepare a fully researched and well-thought-out litigation strategy, in Nova, the Alberta Court of Appeal held that "[l]egal professional privilege, today, can only be justified on the basis of the adversary system. That system accommodates a broad discovery process.” Accordingly, the privilege "should be examined in that light and ... given the narrow rather than the broader scope." 127

In order to protect materials or documents under litigation privilege, a party must prove that they were prepared for the dominant purpose of preparing for litigation. ${ }^{128}$ Though it certainly eases the burden in proving dominant purpose, litigation need not have been commenced at the time of its creation in order to claim litigation privilege over a document. The Alberta Court of Appeal recognized that it is appropriate to allow clients to consult a lawyer and prepare documents in the earliest stages of a conflict. ${ }^{129}$

Ultimately, the factor that will determine, in the early stages, if privilege properly attaches is the full intent of the author or superior when the report is created. ${ }^{130}$ The Court in Moseley held that, "at the time of creation, preparation for litigation must be the dominant purpose." It is not sufficient that litigation was one of the purposes. ${ }^{131}$

Determining the intent at the time of creation of a document raises some interesting subissues. One of the more interesting of that list is the issue of whether or not it is necessary that a lawyer be directly involved in directing the document or personally preparing the document. Nova established the rule that "[t]he privilege accorded to documents prepared in contemplation of litigation applies only if the purpose of instructing solicitors is the 'dominant purpose' for the preparation of the documents in question." ${ }^{\text {132 }}$ Discussing this rule,

Blank, ibid. at para. 26.

Opron Construction v. Alberta (1989), 100 A.R. 58 at paras. 5, 13 (C.A.) [Opron].

Blank, supra note 106 at paras. 27, 34 .

Nova, supra note 121 at para. 21.

See Blank, supra note 106; Opron, supra note 125.

Opron, ibid. The Court in Opron also notes that "a person may contemplate litigation when a long formal process respecting that person starts. That is so even if it is only an investigation which may ultimately lead to a civil suit” (at para. 16).

Ibid. at para. 17; Moseley v. Spray Lakes Sawmills (1980) Ltd. (1996), 184 A.R. 101 (C.A.) [Moseley]. Moseley, ibid. at paras. 21-22.

As quoted in Pechiney Metal Service (Canada) v. Suncor Inc. (1997), 203 A.R. 220 at para. 11 (Q.B.) [emphasis added]. 
the Court in Moseley notes that although the lawyer usually directs or requests a statement or document to be prepared for litigation or anticipated litigation, documents or reports prepared or initiated by clients themselves may be protected. In order to receive such protection though, a party must prove that the creation of the document was done "with a view to providing information for the 'lawyer's brief' ... [and] at the time of creation, preparation for litigation must be the dominant purpose.”"133

In Moseley, the Court ended up allowing disclosure of an insurance adjuster's report because, at the time the report was created, it was not prepared by a lawyer, upon instruction or direction of a lawyer, or even for providing to a lawyer later for legal advice. ${ }^{134}$

A few years after Moseley, in Pechiney, the Court of Appeal once again contemplated whether an incident investigation report met the dominant purpose test and qualified for litigation privilege. ${ }^{135}$ The Court held, consistent with Moseley, that "whether a document falls within the scope of litigation privilege" is determined by assessing "the dominant purpose of the report when the document was physically created." 136 The Court then applied the rule to the facts to find that, in the present case, although the dominant purpose for requesting the report was not to use it in litigation, litigation had begun when the report was created as a document and delivered. The dominant purpose at the critical time was litigation. ${ }^{137}$ Further, relying on Moseley, the majority opinion notes that

[t]he concept of dominant purpose assumes that creation of a document may be motivated by more than one intention. There is no reason in principle why a servient purpose of use in litigation cannot mature into the dominant purpose as the underlying investigation progresses and external events change. Likewise, the predominant intention for requesting a report may, over time, become of lesser significance. ${ }^{138}$

Moseley, supra note 130 at para. 21. The plaintiffs sought production of a statement of one of the individuals involved in an accident. The statement was taken by a consultant insurance adjuster at the time of the accident. The consultant adjuster's report, including the witness statement, was never provided to counsel for professional legal opinion. The report was filed and not considered again until the plaintiff brought suit at a later point in time.

134 Ibid. at para. 27. This case establishes that, at a minimum, a lawyer must be involved and intended as the ultimate recipient of the subject materials.

135 Pechiney Metal Service (Canada) v. Suncor Inc. (1997), 209 A.R. 81 (C.A.) [Pechiney]. Again, the facts are of interest in this case. After the defendant's plant was destroyed by fire, the defendant's manager was instructed by his superiors to investigate and report on the cause of the fire. Before that first report was completed, the defendant had ordered fittings from the plaintiff to repair the damaged plant, and the defendant experienced issues with those fittings. At that time, defendant's counsel instructed the defendant's manager to begin an investigation into the issues of the replacement fittings. As litigation became inevitable over the price of the replacement fittings, defendant's counsel instructed the defendant's manager to compile the two investigations into one report and deliver the single "completed" report directly to outside counsel. Ibid. at paras. 19,8 .

137 Ibid. at paras. 7-9. The Court affirms here that privilege will only attach where the document was prepared for advice to or upon the instruction of a lawyer. Also, this Court extends the concept initiated in Moseley that the point in time at which we look to determine the dominant purpose is the point of the document's creation.

138 Ibid. at para. 10. Interestingly, the dissenting justice in Pechiney was the same justice who wrote the majority opinion in Moseley. In her dissent (at para. 25), she describes that

it is the dominant purpose for preparation of the report that is determinative, and not merely the circumstances existing at the time it is prepared.... Commencement of litigation and delivery to a lawyer are appropriate facts to examine to aid in ascertaining purpose. However, where it is established that the initial purpose was investigative only, litigation, the size of the claim and delivery in themselves cannot be sufficient to change that purpose.

Though the lone voice of dissent in Pechiney, Conrad J.'s dissent may have future influence. Of note on this point, a decision later that same year by an Alberta Master in Edmonton, Witwicky v. Seaboard Life Insurance (1997), 214 A.R. 341 (Q.B.), noted and discussed the “debate” in Pechiney, particularly 
Unlike advice privilege, where the communication must be exclusively between client and solicitor, litigation privilege will protect documents or materials that are created by third parties and communications between solicitors and third parties that are conducted for the dominant purpose of preparing for litigation. ${ }^{139}$

One important distinction between advice privilege and litigation privilege is the length of time that the privilege endures. Because of the policy behind advice privilege, it is a right that will last as long as the client intends. ${ }^{140}$ However, the Supreme Court of Canada, in Blank, clarified that litigation privilege will last only as long as the underlying litigation, but that where "closely related proceedings" continue, the privilege will continue to apply. ${ }^{141}$

Also, in exception to the general rule about litigation files losing protection, materials covered by advice privilege contained within a litigation file remain protected, as advice privilege does not expire. ${ }^{142}$

\section{PRIVILEge APPLIED TO INCIDENT RESPONSE, INVESTIGATION, AND REPORTING}

In the context of incident response, investigation, and reporting, it is important that lawyers have a good grasp on the differences between advice and litigation privilege, when each will apply, and how long it will last. Having that knowledge allows comfort when engaging in full and frank communications at a time when clients need it most, and helps counsel make better decisions about how to treat documents and communications that are very sensitive, particularly if there is a buildup to anticipated or certain litigation. Also, because litigation privilege does expire, counsel should consider if it is more appropriate to invoke advice privilege rather than litigation privilege.

\section{THE SECTION 18 REPORT}

As previously noted, s. 18(3)(b) of the $O H \& S$ Act requires that the prime contractor or employer $^{143}$ prepare a report outlining the circumstances of the accident and also any corrective actions undertaken to prevent a recurrence of a similar incident. As you can imagine, there is the potential that a serious look at the circumstances that led to a serious injury or fatality will reflect unfavourably on the reporting party. The incentive, then, for a fulsome and detailed report is reduced.

However, the $O H \& S$ Act is based on a policy that reaches beyond merely prosecuting and fining employers or prime contractors. The real objective of the legislation is to promote safe workplaces, and one of the primary means of attaining that objective is to motivate the parties responsible for work sites to analyze potential hazards and implement measures to avoid them.

Conrad J.’s caution about convenience of timing.

Blank, supra note 106 at paras. 27, 32.

Ibid. at paras. 8, 32, 37, 50; Descôteaux, supra note 105 at 871.

Blank, ibid. at para. 36 .

Ibid. at paras. 8, 32, 37, 50.

See discussion in Part III, above. For purposes of this discussion, the party will be referred to as the "reporting party." 
So, as a carrot to balance the stick of prosecution and fines, the OH\&S Act provides that a report is "not admissible as evidence for any purpose in a trial arising out of the serious injury or accident, an investigation or public inquiry under the Fatality Inquiries Act or any other action as defined in the Alberta Evidence Act except in prosecution for perjury or for the giving of contradictory evidence." 144

Reporting parties should take comfort, then, that at least the s. 18 report itself is not admissible in any other proceeding, with the prescribed exception, even if the report factors into the investigation by officers who may recommend that the Crown prosecutor lay charges. ${ }^{145}$

\section{DOCUMENTS AND MATERIALS NOT INCLUDED IN THE SECTION 18 REPORT}

Notwithstanding the $O H \& S$ Act's protection of the s. 18 report, counsel should still be aware of and make efforts to preserve a client's right to assert privilege over materials or documents generated during an incident response or investigation. It may turn out that a client is exposed to other types of prosecution or claims, such as property damage or environmental liability, arising out of or related to the incident that resulted in a serious injury or fatality.

Parties should be mindful of the communications, documents, and reports that were generated in an investigation and support the s. 18 report but are not included with or made a part of the protected report. Some of the materials that will not be protected include e-mails amongst response and investigation team members, meeting notes, logbooks, and day books. Reports or studies conducted in the investigation but not ultimately submitted as part of the s. 18 report will not be protected by the OH\&S Act. Also, in circumstances where elements required in privileged communications do not exist, conversations and correspondence with in-house counsel are not protected either.

As described above, the Alberta courts do recognize that investigation reports can qualify for litigation privilege. ${ }^{146}$ It is even possible that litigation privilege can attach before litigation commences. ${ }^{147}$ However, as seen in Moseley and Pechiney, the protected report must meet the dominant purpose test at the time it was created. This can create a difficult situation for investigators. It is usually always the case that, at least initially, investigations are conducted with a primary aim of finding out what happened and formulating corrective actions. After all, that is the policy goal of the $O H \& S$ Act and of careful and prudent prime contractors and employers.

Thankfully, the decision in Pechiney recognizes that it is possible that contemplation of litigation as a purpose for an investigative report can "mature into the dominant purpose as the underlying investigation progresses and external events change." ${ }^{148}$ However, by the time 
the investigative report matures it will have had to have been directed by a lawyer or prepared specifically for a lawyer by clients for the dominant purpose of providing information to the lawyer. ${ }^{149}$

\section{ADVICE OF COUNSEL}

In addition to reports and materials, in-house counsel should be aware of the nature of discussions and communications with clients during incident response and subsequent investigation. In-house counsel may be considered as "employees or former employees" under r. 200(1)(c) of the Alberta Rules of Court. ${ }^{150}$ As such, a lawyer may be compelled to give testimony as an employee having relevant knowledge.

This may be true, as well, for a lawyer working for a company as a consultant or contractor. ${ }^{151}$ Justice Paperny discussed in PCPI that,

[f]rom a policy perspective, this interpretation more accurately reflects current business practices; independent contractors regularly fulfill the functions formerly performed by employees. Permitting examination of those individuals, rather than sheltering behind a technical definition of employee, supports the purposes of examination for discovery by disclosing relevant information before trial. ${ }^{152}$

\section{COMMON INTEREST PRIVILEGE}

In circumstances where the owner and contractor are working together to investigate the incident, compile a report, and implement key recommendations, counsel should consider whether a common interest privilege will apply to opinions or materials prepared on behalf of one of them. ${ }^{153}$ This is especially important as it relates to the investigation report.

In circumstances where an owner anticipates it will be necessary to initiate litigation against its contractor, the investigation report may prove to be key evidence. In such cases, counsel for the owner should retain separate representation and experts, as well as instruct the owner to take control over the investigation report.

Moseley, supra note 130 at paras. 26-27. Pechiney, ibid. There are presentations and writings in circulation that advise counsel to take charge of investigations for the purpose of controlling privilege opportunities. However, as an ethics practice and keeping in mind the policy of incident investigations (to fully investigate the incident and take meaningful corrective actions) the authors caution that counsel should be careful to avoid being overly zealous and risk manipulating investigations for the purpose of protecting information as privileged. Domcan Boundary, supra note 113 at para. 6.

Petro-Canada Products v. Dresser-Rand Canada, 2004 ABCA 144, 348 A.R. 81 at para. 14 [PCPI]. Ibid. at para. 15. See also Klemke Mining, supra note 113.

Common interest privilege applies to facts, advice, or materials exchanged between parties with a common interest. The interest in common may arise from litigation or a commercial transaction and may even apply to documents exchanged or shared between parties despite the fact the parties may be adverse in some respect: see Re YBM Magnex International, 1999 ABQB 793, 252 A.R. 165; Western Canadian Place Ltd. v. Con-Force Products Ltd. (1997), 202 A.R. 19 (Q.B.); Canmore Mountain Villas v. Alberta (Minister of Services and Community Supports), 2009 ABQB 348, [2009] A.J. No. 606 (QL). 


\section{COMMUNICATIONS PROTOCOL}

It is difficult, if not impossible, for counsel to know about and control all aspects of communication and documents generated during an incident response and investigation to properly set the stage for privilege protection. As such, in-house counsel may find it useful to provide some education to clients, before any incident occurs, on the distinction between what is simply confidential information and what might be considered privileged. Ideally, counsel should establish a communication protocol for response and investigation teams in advance of an incident. The protocol should consider both internal communications and external communications.

Internal communications that are usually the most difficult to guide and manage are e-mail messages. At the time of writing this article, individuals working for large corporations and small businesses alike commonly conduct important and confidential business through the use of desktop e-mail and hand-held devices.

Particularly troubling for counsel are the "reply all” and "forward" functions of e-mail messaging. A clear communication protocol may include notes about the confidential and privileged nature of some messages and caution against responding with these two functions. Further, lawyers should caution clients, in general, about using restraint when deciding whether to respond to an e-mail message at all. Multiple responses to an initial message can create exhaustively long message strains that may embed material that would otherwise be protected by privilege.

Because of the ever expanding role that most in-house counsel play within their clients' organizations, there will be times when the lawyer attends discussions and participates with a mix of legal and business advice. In those situations, counsel should establish a meeting protocol that the legal advice portion of the meeting be kept separate from business advice discussions and direct everyone in the room to keep separate sets of notes to clearly distinguish the legal advice communications from business discussions.

External communications often play a key role in incident response and investigation. Press releases and communications to external stakeholders during serious incidents are necessary. Again, counsel may want to work with their communications or media departments and stakeholder liaisons to establish protocols for press releases, statements, or key messaging.

Particularly, to avoid waiving the confidentiality aspect of privilege, clients should avoid publicly repeating the advice provided by lawyers as a justification for a course of action or a decision. A reference that a decision is based on legal advice will not threaten the privilege, but repeating any portion of the advice itself compromises privilege protection over the advice. 


\section{LEGAL HOLDS}

After the incident is over and the s. 18 report has been completed and possibly submitted, parties need to prepare for the possibility of prosecution or other litigation that may follow an injury or fatality incident. The law requires that parties involved in or anticipating litigation must not destroy relevant evidence. Also, in order to defend a charge or prepare a case in other litigation, parties will want relevant evidence for their own defence.

Though not the only qualified parties, legal departments are usually in the best position to take over the document retention function in order to prepare clients for future discovery and preparation of defence. This is best accomplished through a process that has come to be commonly known as a "legal hold." This article does not discuss elements that are desirable or recommended in a corporate document retention policy. The discussion that follows assumes that an efficient and well-considered document retention policy for the company is already in place.

\section{A. Statutory Duty to Retain THE SECtion 18 RePORT AND PRESERVE THE SCENE}

The OH\&S Act requires that a reporting party "shall: ... (c) ensure that a copy of the report is readily available for inspection by an officer." 154 That report must be retained for two years following the date of the serious injury or accident. ${ }^{155}$

In circumstances where Workplace Health and Safety has notified the prime contractor or employer that it has opened an investigation, it will most likely request a copy of the report as soon as it is completed. Notwithstanding having delivered a report, it is still a good practice to retain an exact copy of the original for the two-year statutory period.

Further, the $O H \& S$ Act requires that parties leave the scene of the accident undisturbed. ${ }^{156}$ The statute does not specify how long a party must preserve the scene of the accident, however, common sense and usual practice dictate that the scene should be preserved until officers from Workplace Health and Safety and, in some circumstances, the RCMP, have had a chance to inspect and have agreed to the removal of equipment and restoration of the site.

\section{B. DOCUMENTS AND MATERIALS TO DEFEND AN OCCUPATIONAL HEALTH AND SAFETY CHARgE}

In addition to statutory obligations to preserve the scene and a copy of the s. 18 report, parties should preserve records that will be useful in defending any charges that may be laid by the Crown prosecutor.

OH\&S Act, supra note 2, s. 18(3)(c).

Ibid., s. 18(4).

Ibid. Section 18(6) requires that "[e]xcept as otherwise directed by a Director of Inspection, an occupational health and safety officer or a peace officer, a person shall not disturb the scene of an accident reported under subsection (1) except insofar as is necessary in (a) attending to persons injured or killed, (b) preventing further injuries, and (c) protecting property that is endangered as a result of the accident.” 
It is usually the case that a responsible party will not be notified of charges until very close to the end of the two-year limitation period. Multiple parties and steps are involved in the decision to lay charges and that process usually takes the two years.

At the time a charge is laid, business has moved on. Memories have faded and individuals may have left the company or retired. So it is critical, at the time immediately following the submission of the s. 18 report, to engage in a process of proper document retention and place a legal hold.

\section{PRESERVATION OF EVIDENCE: SPOLIATION AND NEGLIGENT DESTRUCTION OF EVIDENCE}

After wrapping up an investigation, parties should be mindful that although the law sometimes excuses destruction of evidence when done as part of the normal application of a document retention policy, where litigation or prosecution is anticipated or possible, parties are expected to retain relevant evidence. ${ }^{157}$

\section{SPOLIATION}

Meaningful evidence may be destroyed prior to discovery either with intent to better one's position in litigation or through innocent or negligent destruction. Intentional destruction is referred to as spoliation.

In St. Louis, the Supreme Court of Canada established that a party may rebut the presumption created by the rule of “omnia prosumuntur contra spoliatorem," which, when applied, results in a presumption against the wrongdoer that the evidence destroyed would have been unfavourable. ${ }^{158}$

The Alberta Court of Appeal, in McDougall, ${ }^{159}$ recently provided a thoughtful and concise summary of the law relating to spoliation. ${ }^{160}$

\section{NeGLigENT AND UninTENTIONAL DESTRUCTION OF EVIDENCE}

McDougall also provides some background on the possibility that remedies may be available where destruction is "merely reckless or negligent."161 The discussion centres

\section{St. Louis v. The Queen (1896), 25 S.C.R. 649 [St. Louis].}

Ibid. at 652-53.

McDougall v. Black \& Decker Canada, 2008 ABCA 352, 440 A.R. 253 at para. 18 [McDougall] ("Spoliation in law does not occur merely because evidence has been destroyed. Rather, it occurs where a party has intentionally destroyed evidence relevant to ongoing or contemplated litigation in circumstances where a reasonable inference can be drawn that the evidence was destroyed to affect the litigation”).

Ibid. at para. 29. There is not room in this article to discuss spoliation beyond recognizing it as an issue. The authors recommend Conrad J.'s very helpful summary of Canadian law on spoliation.

Ibid. at para. 23, citing Lamont Health Care Centre v. Delnor Construction Ltd., 2003 ABQB 998, 349 A.R. 309 [Lamont]. The Court in Lamont did not find the destroying party to be negligent on the facts. In this case, several insurers were involved and had been given opportunity to inspect a roof that had been burned during construction. One of the insurers did not receive notice of the demolition and claimed spoliation of evidence. Because the various insurers had been given a month or more to inspect the roof prior to demolition and also because the party that demolished the roof did not selectively preserve evidence and was not trying to rely on its own evidence obtained through the demolition 
around whether it would be appropriate to apply the presumption where the destruction is not maliciously intentional but merely negligent. The Court in McDougall makes the distinction that "unintentional destruction of evidence is not spoliation, and it is not appropriate to presume that missing evidence would tell against the person destroying it where the destruction is unintentional and the trier of fact cannot draw the adverse inference that the evidence was destroyed because it would tell against the spoliator." ${ }^{162}$

\section{REMEDIES}

Where a party brings an application claiming the other party has destroyed relevant evidence, there are a variety of remedies that may be sought. The appropriate remedy will depend on the facts and circumstances of the case, whether or not the destruction was intentional, and what remedies or sanctioning tools may be available to the pretrial court to avoid abuse of process under the rules of procedure.

The primary remedy for spoliation is the presumption against the party that destroys the evidence. ${ }^{163}$ However, there is a possibility that contract or tort remedies may be available, as well as sanctions available to a case management judge. ${ }^{164}$

\section{WHAT TO RETAIN?}

The majority of case law in Alberta relating to spoliation and negligent destruction of evidence arises from disturbance or removal of evidence following a fire or accident. In the case of accidents involving occupational injuries or fatalities, the $O H \& S$ Act provides for non-disturbance of the scene, which allows Workplace Health and Safety and, in some circumstances, the RCMP, to collect evidence. However, a person that might be charged under the $O H \& S$ Act will want to preserve other evidence that could aid in developing a defence after charges have been laid. Also, in circumstances where the party knows or should know that other litigation will follow, to avoid negligent destruction of evidence, they should preserve relevant evidence. This evidence will most likely consist of documents, files, and electronic evidence.

There are many papers and presentations about electronic discovery and proper storage procedures for electronic evidence and this article will not go into detail about electronic

process, the Court found that there was not an abuse of process and no sanction was warranted.

McDougall, ibid. at para. 25.

163 See St. Louis, supra note 157; McDougall, ibid.

164 The Court in McDougall discusses cases from other jurisdictions and notes that "[t]hese cases suggest there is some judicial recognition that the remedy described in St. Louis may not be enough to deal with the prejudice caused by the intentional destruction of evidence" (ibid. at para. 22). See also Dreco Energy Services Ltd. v. Wenzel, 2005 ABCA 185, 371 A.R. 11, where the Court considered the erasure of computer records and determined that the sanctions imposed by the case management judge were inadequate. However, in a follow-up to that decision, the Court was faced with the factual evidence that though computer records had been erased, there was doubt as to whether any relevant evidence had actually been lost. The Court discussed the long history of this case and that spoliation issues are deeply embedded in the facts. Justice Greckol noted that because of the intricacies of and necessity to heavily consider the facts, "[t]he Trial Judge is in the best position to make this determination. In my view, factual and credibility findings ought not to be made in case management at this stage, weeks before a trial estimated to require some six months of hearing" (see Dreco Energy Services Ltd. v. Wenzel, 2008 ABQB 489, [2008] A.J. No. 890 at para. 26 (QL)). 
storage solutions other than to advise that this is an area of data that should be included in the legal hold protocol.

When sorting through the material and making choices for retention, relevant evidence breaks down into three categories: (1) records relating to the incident and investigation into its causes; (2) records relating to the incident response; and (3) records relating to the fulfillment of prime contractor or employer duties required by the OH\&S Act.

Records relating to the incident itself that may be useful include witness statements, properly catalogued photographs, maps and drawings, engineering and other technical studies, or reports of experts.

Parties may also, in some circumstances, find themselves involved in litigation arising out of the incident response. Records that may be useful to defend response activities may include incident commander briefing notes and updates, as well as documents and training materials describing the policies and procedures that govern the roles and protocols of responders.

Last, and maybe most important, parties will need to preserve documents, materials, and records that provide evidence of how that party fulfilled the role of prime contractor or employer as required under the $O H \& S$ Act. Records that might be relevant include copies of policies and guidelines for site safety, descriptions of the detailed systems and procedures for managing site safety, as well as copies of audits or inspection reports, examples of "tailgate" or "toolbox" meeting notes, and pre-job hazard assessment forms.

\section{Systems And Procedures to Have in Place BEFORE AN INCIDENT}

Appendix A is a tip sheet of recommendations to guide incident response through the initial minutes, hours, and days following an incident. However, there are several systems and procedures that, if in place before an incident occurs, are invaluable in helping legal counsel manage the legal issues that are likely to arise from an incident. Following is a list of such systems and procedures:

- Clearly designate the prime contractor in the contract between the owner and the contractor; ${ }^{165}$

- Ensure that the roles of the parties post-incident are clearly delineated.

In many cases, project owners delegate the day to day management of work and a work site to a contractor yet retain the role of prime contractor. This applies equally to large construction and well-site drilling and completions. In such instances, the contractor ends up with the most in-depth knowledge of the work site, yet the owner has the statutory responsibility to investigate and report on an incident. ${ }^{166}$ Consider carefully in the contract 
what the roles of reporting and investigating will be, most notably which party has the final say on the final s. 18 report. Also, clearly establish in the contract guidelines for the sharing of documentation and evidence arising from the investigation, as there is a high potential for the owner's interests to conflict with those of its management contractor in an investigation;

- Drug and alcohol policy expressly allows post-incident testing

Preferably, the owner's and contractor's policies will provide for consent and waiver at time of hire, with disciplinary actions for refusal; ${ }^{167}$

- Consent at time of hire for medical information or autopsy results post-incident

As with drug and alcohol testing, policies should preferably establish that, at the time of hire, the worker provides consent for release of medical information or post-incident autopsy results where used for the legitimate purpose of investigating root and contributing causes of an incident and making recommendations. As a note of caution, such policies must still follow the security procedures required by FOIPP;

- Education on privilege and confidentiality

Ensure that managers who will be part of the decision-making related to incidents, as well as investigators or team leaders, understand the limitations of legal privilege. Counsel can prepare in advance by stressing the importance of confidentiality and basic rules of the two types of privilege, as well as the common sense aspects of maintaining confidentiality;

\section{- Communication protocols}

Prior to any actual incident, counsel should aid in establishing a communication protocol to ensure not only effective and clear lines of communication during incident response but also the maintenance of confidentiality and privilege, where available. Such a protocol should consider both internal communications as well as external communications and, where necessary, provide in contractor agreements that they will follow those protocols; ${ }^{168}$

\section{- Document retention policy}

Specifically for the purpose of preserving evidence and materials that Workplace Health and Safety might wish to see, companies should have specific procedures in place for a legal hold applicable to occupational safety information and materials. The legal hold procedures will need to coordinate with the company's larger document management and retention policy; ${ }^{169}$ 
- Triggers to engage legal counsel

Most, if not all, companies have established incident response systems and teams. By, necessity, the primary objective is focused on dealing directly with the problems caused by the incident. Legal counsel can provide primers or tip sheets in advance to help deal with matters in the initial minutes and hours, such as those described in Appendix A, and also establish triggers that will require involvement of legal counsel. Above all, legal counsel should aim for a system that allows them to provide advice and counsel without getting in the way of the primary objective, which is incident response and investigation.

\section{APPENDix A \\ TIPS AND SUgGESTIONS FOR THE INITIAL HOURS AND DAYS IMMEDIATELY FOLLOWING THE INCIDENT}

\section{IMMEDIATE RESPONSE TO AID PEOPLE AND PROPERTY}

- Contact emergency response to aid any injured workers or remove bodies of killed workers and address any other related site emergencies, such as fire, spill, dangerous conditions, etc.

- Do not disturb the scene except as necessary to attend to persons injured or killed, prevent further injuries, and protect property ${ }^{170}$

- Evacuate as necessary and provide appropriate support for workers who are not physically injured but may be suffering shock or critical incident stress

\section{CORPORATE COMMUNICATION AND REPORTING}

- Consult any contracts with construction contractors or field site managers regarding, among other applicable issues, coordinating incident response, press or public information releases, and drug testing policies

- Identify the designated person to perform the preliminary investigation ("Incident Coordinator" and where this term is used it may include a delegate) under terms of contract or otherwise

- Remove all persons other than the Incident Coordinator and necessary helpers from the immediate vicinity of the incident location

- Evacuate as necessary to forestall inappropriate communication about the incident and be aware of instant communication, including photographs of the incident taken on personal hand-held devices that, if made public, could seriously affect any company communication plan, including the communication with the families of injured or killed workers 
- Determine if the incident is a reportable incident under s. 18(2) of the OH\&S Act and report if need be (Tel: 1.866.415.8690)

- Ensure appropriate communication with supervisors, union officials, family, or others as required in relation to the injured or killed person

\section{PRELIMINARY INVESTIGATION}

- Physically secure the site

- Record the time, date, and location of the incident and any persons injured or killed or any property damage

- Keep a log of any changes made to the scene as a result of disturbance to provide aid (for instance the movement of machinery to assist a trapped worker)

- Take photographs of the scene (log all photos and provide annotations where necessary)

- Determine which individuals may have (1) witnessed the incident; (2) witnessed the scene leading up to the incident; or (3) witnessed any actions in the preceding minutes, hours, or days that could be relevant to the investigation

- Gather a list of all relevant witnesses with names, positions, and contact information

- If applicable, request that the employer arrange for testing in accordance with any applicable drug and alcohol policy

\section{CONSIDER WHETHER SOLICITOR-CLIENT PRIVILEGE IS APPROPRIATE}

- Implement and provide refresher information relating to communication protocols

- If applicable, ensure all notes, documentation, electronic data, etc. are marked with words such as "privileged and confidential”

\section{FURTHER INVESTIGATION AND PRESERVATION OF EVIDENCE}

- Obtain written witness statements where advisable and available

- Keep a log of all information given to Workplace Health and Safety officers

- Keep a log of all information requested by, but not yet given to, Workplace Health and Safety officers

- Keep a log of all substances, materials, products, tools, appliances or equipment, and tools seized by and samples taken by Workplace Health and Safety officers and obtain and collect receipts for the same 
- Ensure that the person dedicated to interface with Workplace Health and Safety officers keeps a record of the scope of the investigation, including the witnesses who are interviewed

- Conduct a debriefing with witnesses who are interviewed by Workplace Health and Safety officers

- Manage the turnover of the closed site to operations when the site is cleared for reopening by Workplace Health and Safety officers

\section{Preparation OF SECTION 18 REPORT}

- A s. 18 report will be requested on a very short time frame when initial responders are exhausted and potentially mentally fatigued by the investigation process — make critical incident stress debriefing or other support available

- Develop the report with the assistance of counsel to ensure that the report provides an adequate picture of both the incident and the events leading up to the incident

- Start the due diligence process with the report and include information about the things that were done correctly, such as hazard assessments, training, management of the site, and processes implemented to ensure the $O H \& S$ Act was followed

- Include steps to ensure that the incident does not occur again and follow up to ensure these steps have been taken

- Clearly mark the report as having been prepared pursuant to s. 18 of the OH\&S Act 